\title{
Renata Karkowska
}

Uniwersytet Warszawski

e-mail: rkarkowska@wz.uw.edu.pl

\section{Igor Kravchuk}

Tarnopolski Narodowy Uniwersytet Ekonomiczny

e-mail: igskrav@gmail.com

\section{BADANIE CYKLICZNOŚCI \\ NA RYNKU INSTRUMENTÓW FINANSOWYCH}

CYCLICAL ANALYSIS

\section{ON THE FINANCIAL INSTRUMENT MARKET}

DOI: $10.15611 /$ pn.2017.489.13

JEL Classification: E30, G01, G12, G17

Streszczenie: Celem badania jest weryfikacja zjawiska cykliczności na rynku papierów wartościowych i derywatów. W badaniu została przyjęta metoda punktów zwrotnych, z kolei identyfikację szczytów i dna rynków dokonano na podstawie metody Claessensa. Ponadto analizie zostanie poddany poziom synchronizacji cykliczności wahań wybranych wskaźników rynkowych w krajach o zróżnicowanym poziomie rozwoju gospodarczego. Nasilające się zjawiska synchronizacji rynków powodują większą przewidywalność zachodzących na nich zmian, ale z drugiej strony potęgują ryzyko systemowe. Próba badawcza obejmuje rynek rozwinięty - Niemcy, rynki wschodzące - Polska, Rosja i rynek graniczny - Ukraina. Badanie zostało przeprowadzone w latach 1996-2015. Wyniki badania potwierdzają obecność znacznego poziomu synchronizacji cykli, co jest potwierdzeniem istotnych powiązań między rynkami. Zjawisko to może się nasilać w oparciu o efekt zarażania przy realizacji niestabilności finansowej, w tym systemowej.

Słowa kluczowe: cykl koniunkturalny, rynek papierów wartościowych, instrumenty pochodne, efekt zarażania.

Summary: The purpose of the study is to verify the cyclical nature of the securities and derivatives market. In the study, the method of turning points was adopted, while the identification of the peaks and bottoms of markets was made on the basis of the Claessens method. In addition, the level of cyclical fluctuations in selected market indicators of different countries was analyzed. In order to determine the level of synchronization of markets of different levels of development, the coefficients of concordance were calculated. The research sample includes the developed market - Germany, emerging markets - Poland and Russia and the border market - Ukraine. The study was conducted between 1996 and 2015. The results of the study confirm the existence of a significant level of cycle synchronization, which is 
a confirmation of important links between markets. This phenomenon may be enhanced based on the contagion effect in the implementation of financial instability in the system.

Keywords: business cycle, securities market, derivatives, contagion effect.

\section{Wstęp}

Wśród analiz nad rozwojem gospodarek istotne miejsce zajmują badania zjawiska cykliczności na rynku finansowym, estymacja i prognozowanie długości faz wzrostu/spadku koniunktury. Znajomość cykli w szczególności upodobali sobie inwestorzy/zwolennicy analizy technicznej, ale ma ona również ogromne znaczenie w praktyce gospodarczej, ponieważ pozwala optymalizować decyzje i przewidywać konsekwencje ryzyka systemowego. Badania empiryczne nad strukturą i synchronizacją cykli koniunkturalnych podkreślają dwa podejścia. Pierwsze oparte na analizie kształtu cykli koniunkturalnych w wybranych krajach/grupach w czasie i ich stopnia synchronizacji. Druga z kolei grupa badań wskazuje na czynniki determinujące poziom synchronizacji cykli. Wyniki obydwu podejść nabierają istotnego znaczenia w procesie globalizacji, w szczególności w kontekście krajów rozwijających się, które upodabniają się do gospodarek rozwiniętych, a tym samym zwiększają swoje znaczenie gospodarcze. Podstawową przyczyną rosnącej synchronizacji cykli koniunkturalnych są rosnące przepływy kapitałowe w skali międzynarodowej, stąd badania nad identyfikacją struktury faz cykli koniunkturalnych dla różnych grup instrumentów finansowych i grup krajów powinno wzbogacić dotychczasowy dorobek literatury.

\section{Cel badawczy i hipotezy}

Badanie ma na celu weryfikację zjawiska cykliczności na rynku papierów wartościowych i derywatów i jego wpływu na materializację ryzyka systemowego w krajach o zróżnicowanym poziomie rozwoju gospodarczego (rynek rozwinięty - Niemcy, rynki wschodzące - Polska, Rosja i rynek graniczny - Ukraina). Nasilające się zjawiska synchronizacji rynków powodują większą przewidywalność zachodzących na nich zmian, ale z drugiej strony potęgują ryzyko systemowe. Stąd w kontekście przyjętego celu badawczego postawiono następujące hipotezy badawcze:

H1: Pomimo globalizacji rynków finansowych trwałości fazy wzrostu/spadku wartość instrumentów finansowych jest uzależniona od rozwoju gospodarczego kraju.

Inwestowanie na rynku kapitałowym jest przedsięwzięciem wymagającym wiedzy i doświadczenia, ale i opanowania, co powoduje, że eskalacja zmienności rynkowej z reguły powinna ograniczać chęć inwestorów do podejmowania ryzyka. I przeciwnie okresy hossy przyciągają tych, którzy akceptują niższy poziom niepewności. Badania jednak potwierdzają, że zjawisko to przebiega odmiennie w krajach o zróżnicowanym poziomie rozwoju. Stąd przyjęto założenie, że: 
H2: W krajach rozwiniętych długość trwania fazy wzrostu na rynku finansowym wykazuje tendencję do wydłużania w porównaniu z fazą spadku.

H3: Rynki krajów rozwijających się charakteryzują się wysoką amplitudą zmian wartości aktywów, co świadczy o wysokiej zmienności i niestabilności rynku.

Badanie zostało poprzedzone studiami literaturowymi (teoretycznymi i empirycznymi).

\subsection{Przegląd literatury}

Algorytm identyfikacji cykli na podstawie punktów zwrotnych (turning points) opracowali Bry i Boschan [1971] jako algorytm BB, a rozszerzyli Harding i Pagan [2002]. Metoda punktów zwrotnych jest stosowana również przez NBER USA (National Bureau of Economic Research) do definiowania cykli gospodarczych. Korzystanie z algorytmu BB dla identyfikacji boomów-załamań na rynkach aktywów, ustalenia cykli finansowych, w tym na rynku akcji, szczegółowo opisane zostało w pracach: [Pagan, Sossounov 2003; Edwards, Biscarri, De Gracia 2003; Jaeger, Schuknecht 2004 oraz Claessens i in. 2011]. Claessens i in. [2011], przeprowadzając obliczenia cykli (na podstawie wskaźnika kompozytowego dla rynku nieruchomości, akcji i rynku kredytowego) dla 21 krajów rozwiniętych należących do grupy OECD, ustalili jako warunki obrachunków minimalny czas trwania poszczególnych faz nie mniejszy niż 2 kwartały, a cyklu w całości - nie mniejszy niż 5 kwartałów. Pagan i Sossounov [2003], opierając się na teorii Dow o dynamice cen na rynku akcji, używali jako minimalnego czasu trwania fazy na rynku akcji 4 miesięcy, jednak w przypadku spadku cen o $20 \%$ i więcej nie uwzględniali ograniczenia i za dodatkową fazę uważali okres jednomiesięczny.

Szczyt w wartościach danych finansowych $\left(f_{t}\right)$ został zidentyfikowany na podstawie nierówności [Claessens i in. 2011]:

$$
\left\{\left[f_{t}-f_{t-2}>0,\left(f_{t}-f_{t-1}\right)>0\right] \text { ma }\left\{\left[f_{t+2}-f_{t}<0,\left(f_{t+1}-f_{t}\right)<0\right]\right\} .\right.
$$

$\mathrm{Z}$ kolei dno oblicza się jako:

$$
\left\{\left[f_{t}-f_{t-2}<0,\left(f_{t}-f_{t-1}\right)<0\right] \text { ma }\left\{\left[f_{t+2}-f_{t}>0,\left(f_{t+1}-f_{t}\right)>0\right]\right\}\right. \text {. }
$$

Jako główne wskaźniki cyklu przyjęto za [Claessens i in. 2011; Agnello, Schuknecht 2009; Jaeger, Schuknecht 2004] odpowiednio:

(1) czas trwania faz wzrostu lub spadku: $D$ - liczba kwartałów między dnem a szczytem, $T P$ - przy wzroście i między dnem a szczytem, $P T$ - w fazie spadku;

(2) amplitudę wzrostu/spadku: $A$ - różnica między wskaźnikiem rynku w momencie szczytu i dna (w fazie upadku) i między dnem a szczytem (w fazie wzrostu);

(3) skumulowane zmiany (Z), które są obliczane na podstawie aproksymacji trójkątnej w następujący sposób: $C_{i}=\left(D_{i} \cdot A_{i}\right) \cdot 0,5$ (logarytmiczne lub procentowe).

W ramach cyklu finansowego w pracach Claessensa i in. [2011], Agnello i Schuknechta [2009] boomy i załamania rynku są identyfikowane, jeżeli zmiany wskaźników 
(lub skumulowane zmiany) podczas wzrostu (spadku) znajdują się w górnym (dolnym) kwartylu całej próby. Metoda identyfikacji boomów-załamań ma pewną wadę, ponieważ w każdym przypadku w analizowanym okresie $25 \%$ fazy wzrostu i spadku będzie oznaczone jako boom lub załamanie, dlatego bardziej akceptowana dla ich określenia jest metoda filtrów częstotliwościowych. Stosowanie metody punktów zwrotnych jest dopuszczalne do głębszej analizy wahań rynku na podstawie cykliczności. Badania w zakresie synchronizacji cykli koniunkturalnych prowadzili Akin [2006] oraz Frankel i Rose [1998, s. 1009-1025].

\section{Opis metody badawczej}

Badanie rynków papierów wartościowych i derywatów w krajach o różnym poziomie rozwoju gospodarczego metodą punktów zwrotnych ma na celu ocenę poziomu cykliczności i jego wpływu na materializację ryzyka systemowego. Ponadto analizie zostanie poddany poziom synchronizacji cykliczności wahań wybranych wskaźników rynkowych różnych krajów. Próba badawcza obejmuje rynek rozwinięty - Niemcy, rynki wschodzące - Polska, Rosja i rynek graniczny - Ukraina. W szczególności:

- Do oceny rynków akcji stosowano dane kwartalne (na koniec okresu) wartości indeksów giełdowych ${ }^{1}$, które skorygowano indeksem cen konsumpcyjnych z wartością $100 \mathrm{w} 2010$ roku².

- Analiza rynków dłużnych papierów wartościowych wykonana została na podstawie informacji kwartalnej o łącznej wartości papierów dłużnych (wszystkich emitentów i terminów zapadalności), znajdujących się w obrocie (według danych BIS), i objęła urealnienie wartości nominalnej. Dla rynku dłużnych instrumentów finansowych na Ukrainie ta informacja nie była dostępna.

- Do badania rynków derywatów zastosowano dane dotyczące liczby otwartych pozycji (LOP) ${ }^{3}$. Wskaźnik liczby otwartych pozycji na rynku w Polsce i Rosji zawiera dane zbiorowe dotyczące wszystkich kontraktów terminowych i opcji na koniec każdego okresu. Dla rynku Ukrainy wykorzystano dane dotyczące liczby kontraktów terminowych na indeks UX. O rynku derywatów w Niemczech nie znaleziono publicznie dostępnych zagregowanych danych (tylko roczne dane dostępne na stronie internetowej Bundesbanku).

Do obliczania cykli w oparciu o metodę punktów zwrotnych zostały użyte realne zlogarytmizowane wartości indeksów giełdowych i wartości rynku dłużnych papierów wartościowych, a także logarytmiczne wartości liczby otwartych pozycji na rynku instrumentów pochodnych.

Identyfikacji szczytów i dna rynków dokonano na podstawie wzorów (1), (2). Z kolei jako wskaźniki cykli wykorzystano: czas trwania, amplitudę i skumulowane

\footnotetext{
${ }^{1}$ Dane wartości indeksów DAX, WIG, RTS, PFTS uzyskano na stronie internetowej Investing.com.

${ }^{2}$ Dane indeksów cen konsumpcyjnych uzyskano z International Financial Statistics IMF.

${ }^{3}$ Dane o LOP uzyskano z GPW, ukraińskiej giełdy (UX), moskiewskiej giełdy (MOEX).
} 
zmiany wartości indeksów. Jeżeli w ciągu rosnącej (spadkowej) fazy obserwujemy okres zmian przeciwnego kierunku, które dalej nie potwierdzają się ruchem w tym kierunku, to ten odcinek jest korektą i nie jest brany pod uwagę jako zmiana fazy. Faza wzrostu jest obliczana od pierwszego kwartału, kiedy odnotowano wzrost, do kwartału (włącznie), gdy osiągnięto maksimum. Z kolei faza spadku - od pierwszego kwartału, kiedy odnotowano spadek, do kwartału (włącznie), gdy osiągnięto minimum. Amplituda to różnica między wartościami logarytmów w okresach szczytu i okresach, gdy osiągnięto dno. Poziom synchronizacji cykli odrębnych segmentów rynku zbywalnych instrumentów finansowych w różnych krajach został obliczony na podstawie indeksu konkordancji $C I_{x y}$ [Claessens i in. 2011]:

$$
C I_{x y}=\frac{1}{T} \sum_{t=1}^{T}\left[C_{t}^{x} \cdot C_{t}^{y}+\left(1-C_{t}^{x}\right) \cdot\left(1-C_{t}^{y}\right),\right.
$$

gdzie $\mathrm{C}_{t}^{x}, \mathrm{C}_{t}^{y}$ - zmienne binarne, które mają wartość 0 , kiedy wartości zmiennych $x$, $y$ (wskaźników odrębnych segmentów rynku lub jednego wskaźnika dla różnych krajów) są w fazie spadku i 1 - w fazie wzrostu.

\section{Wyniki}

Metoda punktów zwrotnych pozwala głębiej przeanalizować fluktuacje rynkowe na podstawie opisu ich cykliczności.

Tabela 1. Trwałość cykli na rynku akcji

\begin{tabular}{|c|c|c|c|}
\hline Cykl & Trwałość & Cykl & Trwałość \\
\hline \multicolumn{2}{|l|}{ Ukraina } & \multicolumn{2}{|c|}{ Niemcy } \\
\hline 1 kw. $2000-4$ kw. 2007 & 32 & 4 kw. $1993-1$ kw. 2000 & 26 \\
\hline 4 kw. 2007 - 1 kw. 2011 & 14 & 1 kw. $2000-1$ kw. 2002 & 9 \\
\hline \multirow[t]{2}{*}{1 kw. $2011-2$ kw. 2014} & 14 & 1 kw. $2002-2$ kw. 2007 & 22 \\
\hline & & 2 kw. $2007-1$ kw. 2015 & 32 \\
\hline Średnia trwałość & 20 & Średnia trwałość & 20,25 \\
\hline \multicolumn{2}{|l|}{ Rosja } & \multicolumn{2}{|c|}{ Polska } \\
\hline 3 kw. 1997 - 1 kw. 2000 & 11 & 1 kw. $1994-3$ kw. 1997 & 15 \\
\hline 1 kw. $2000-1$ kw. 2002 & 9 & 3 kw. $1997-1$ kw. 2000 & 11 \\
\hline 1 kw. $2002-4$ kw. 2007 & 24 & 1 kw. $2000-1$ kw. 2002 & 9 \\
\hline 4 kw. 2007 - 1 kw. 2011 & 14 & 1 kw. $2002-2$ kw. 2007 & 22 \\
\hline 1 kw. $2011-4$ kw. 2012 & 8 & 2 kw. $2007-1$ kw. 2011 & 16 \\
\hline \multirow[t]{2}{*}{4 kw. $2012-2$ kw. 2015} & 11 & 1 kw. $2011-4$ kw. 2012 & 8 \\
\hline & & 3 kw. $2014-3$ kw. 2014 & 8 \\
\hline Średnia trwałość & 12,83 & Średnia trwałość & 12,71 \\
\hline
\end{tabular}

Źródło: opracowanie własne. 
Dla rynku akcji na Ukrainie i w Niemczech (tab. 1) średnia trwałość cyklu (od szczytu do szczytu) wynosi około 20 kwartałów, a dla rosyjskiego i polskiego rynku około 13 kwartałów. Dla wszystkich rynków akcji można obserwować najdłuższy cykl przed światowym kryzysem finansowym (tab. 1), który trwał od 2002 do 2007 roku, a na Ukrainie ten cykl trwał od początku 2000 do końca 2007 roku (32 kwartały). Pełną zbieżność w horyzoncie czasowym i czasie trwania cyklu możemy zauważyć na rynkach akcji Ukrainy i Rosji od 4 kw. 2007 do 1 kw. 2011 roku (14 kwartałów). Na przestrzeni analizowanego okresu badania na rynkach akcji Ukrainy i Polski możemy obserwować zmniejszenie i wyrównanie czasu trwania cyklu na poziomie odpowiednio 14 i 8 kwartałów. Z kolei rynek akcji w Niemczech charakteryzuje się wzrostem czasu trwania cyklu do 32 kwartałów.

Na rynku dłużnym (tab. 2) zidentyfikowano znaczną ilość cykli w zakresie obrotu papierami wartościowymi w Niemczech (7 cykli) ich trwałość zmniejszyła się z 25 kwartałów do 5-8 kwartałów, czyli na rynku danego kraju można zaobserwować wzrost wahań spowodowany ewentualnym odzwierciedleniem kryzysu zadłużenia w niektórych krajach UE. Na polskim rynku dłużnym zidentyfikowano 2 cykle o średniej trwałości 12 kwartałów, a w Rosji - tylko 1 długi cykl (23 kwartały). Mniejszą liczbę cykli dla rynków rozwijających się z badanej próby można byłoby wyjaśnić częściowo mniejszym okresem analizy danych (z 4 kw. 2003 roku dla Polski oraz z 1 kw. 2004 roku dla Rosji, a dla Niemiec - z 1 kw. 1991 roku), jednak 5 z 7 cykli na rynku w Niemczech zidentyfikowano w 4 kw. 2004 roku.

Tabela 2. Trwałość cykli na rynku dłużnych papierów wartościowych

\begin{tabular}{|c|c|c|c|}
\hline Cykl & Trwałość & Cykl & Trwałość \\
\hline \multicolumn{2}{|c|}{ Polska } & \multicolumn{2}{|l|}{ Rosja } \\
\hline 2 kw. $2008-2$ kw. 2011 & 13 & 2 kw. $2008-4$ kw. 2013 & 23 \\
\hline 2 kw. $2011-4$ kw. 2013 & 11 & & \\
\hline Średnia trwałość & 12 & & \\
\hline \multicolumn{4}{|c|}{ Niemcy } \\
\hline 4 kw. $1996-4$ kw. 1998 & 9 & 3 kw. 2009 - 2 kw. 2011 & 8 \\
\hline 4 kw. $1998-4$ kw. 2004 & 25 & 2 kw. $2011-4$ kw. 2012 & 7 \\
\hline 4 kw. $2004-2$ kw. 2008 & 15 & 4 kw. $2012-4$ kw. 2013 & 5 \\
\hline 2 kw. $2008-3$ kw. 2009 & 6 & & \\
\hline Średnia trwałość & \multicolumn{3}{|l|}{10,7} \\
\hline
\end{tabular}

Źródło: opracowanie własne.

Niewielka ilość cykli dla rynków dłużnych papierów wartościowych Rosji i Polski może być częściowo wyjaśniona słabym rozwojem dłużnego segmentu rynków papierów wartościowych, ponieważ zdecydowana większość przedsiębiorstw finansowana jest kredytem bankowym. Ponadto możliwości rynków obligacji skarbowych 
nie są stosowane w takim stopniu jak w Niemczech, gdzie rynek obligacji jest jednym z największych na świecie i służy bardzo często jako obiekt bezpiecznych inwestycji (flight to quality). Trwałość cykli rynku derywatów wykazuje podobieństwo na Ukrainie i w Rosji, jednak należy wziąć pod uwagę, że dla ukraińskiego rynku dostępne są dane tylko z 2010 roku. Na polskim rynku obserwujemy obecność cykli większej częstotliwości - zidentyfikowano 4 cykle (tab. 3).

Tabela 3. Trwałość cykli na rynku derywatów

\begin{tabular}{|c|c|c|c|}
\hline Cykl & Trwałość & Cykl & Trwałość \\
\hline \multicolumn{2}{|l|}{ Rosja } & \multicolumn{2}{|c|}{ Ukraina } \\
\hline 2 kw. $2008-2$ kw. 2011 & 13 & 4 kw. $2011-3$ kw. 2014 & 12 \\
\hline 2 kw. $2011-3$ kw. 2014 & 14 & Średnia trwałość & 12 \\
\hline \multicolumn{4}{|c|}{ Polska } \\
\hline 2 kw. $2002-3$ kw. 2005 & 14 & 2 kw. 2007 - 1 kw. 2011 & 6 \\
\hline 3 kw. $2005-2$ kw. 2007 & 8 & 1 kw. $2011-1$ kw. 2013 & 9 \\
\hline Średnia trwałość & 9,25 & & \\
\hline
\end{tabular}

Źródło: opracowanie własne.

Na podstawie analizy wskaźników faz cykli w segmentach rynku zbywalnych instrumentów finansowych (tab. 4) możemy wyodrębnić następujące ich cechy:

1. Dla przeważającej części segmentów rynku (z wyjątkiem instrumentów pochodnych Ukrainy) istnieje tendencja do większej trwałości fazy wzrostu niż spadku. Na przykład na rynku dłużnych papierów wartościowych w Rosji faza wzrostu prawie 3,3 razy przekracza fazę spadku cyklu, na rynku akcji w Niemczech - około 2,5 razy.

2. Dla rynków akcji najdłuższe fazy wzrostu są charakterystyczne dla rozwiniętych rynków - ponad 13 kwartałów dla Niemiec. Na ukraińskim rynku akcji cykl wzrostu jest wyższy (około 10 kwartałów) aniżeli na rynkach rozwijających się (ponad 7 kwartałów). Jednak na Ukrainie możemy zaobserwować okresy o najdłuższej trwałości faz spadku - 7,5 kwartału, najmniejsza długość faz tego rodzaju jest charakterystyczna dla rynków, które rozwijają się (powyżej 4 kwartałów).

3. Odmienne wyniki dotyczące czasu trwania fazy wzrostu są charakterystyczne dla rynku dłużnych papierów wartościowych: najdłuższe fazy w Rosji (18 kwartałów), najkrótsze na rynku niemieckim - 7,4 kwartału. Fazy spadku dla wszystkich rynków mają prawie taką samą długość - średnio 4-5 kwartałów.

4. Na rynku pochodnych instrumentów finansowych najdłuższa trwałość faz wzrostu jest charakterystyczna dla rynku rosyjskiego, a fazy spadku mają podobną trwałość na rynkach Ukrainy i Polski.

5. Najwyższą amplitudę na rynku akcji obserwujemy dla rosnących faz rynku Ukrainy, na rynku dłużnych zbywalnych instrumentów finansowych i derywatów w Rosji (pomimo wysokiej trwałości fazy wzrostu). Najwyższa amplituda spadku 
jest charakterystyczna dla rynku akcji i derywatów Ukrainy. Takie dane świadczą o wysokiej zmienności i niestabilności rynku.

6. Dość wysokimi wartościami skumulowanego wzrostu rynku akcji i największymi wartościami skumulowanymi spadku we wszystkich segmentach rynku instrumentów finansowych wyróżnia się Ukraina, co potwierdza wysoką kruchość rynku i wrażliwość na wstrząsy. Zwłaszcza w okresie światowego kryzysu finansowego na rynku akcji Ukrainy skumulowany spadek wyniósł ponad 6 razy. Największy skumulowany wzrost zanotowano na rynku derywatów Rosji, z uwzględnieniem, że rozwój rynku zaczął się w okresie intensywnego rozwoju rynku instrumentów finansowych w całości w okresie przed światowym kryzysem finansowym. W szczególności długa faza wzrostu (od 1 kw. 2001 do 2 kw. 2008 roku) zapewniła skumulowany wzrost liczby otwartych pozycji aż 76 razy. Niewielkie skumulowane zmiany możemy

Tabela 4. Podstawowe dane faz cykli na rynku zbywalnych instrumentów finansowych

\begin{tabular}{|l|c|c|c|c|c|c|}
\hline \multirow{2}{*}{ Kraj } & \multicolumn{7}{c|}{ Faza wzrostu } & \multicolumn{3}{c|}{ Faza spadku } \\
\cline { 2 - 7 } & D & A & C & D & A & C \\
\hline \multirow{7}{*}{ Niemcy } & 13,60 & 0,81 & 7,20 & 5,5 & $-0,58$ & $-1,59$ \\
& $(17,00)$ & $(1,00)$ & $(9,61)$ & $(5,5)$ & $(-0,65)$ & $(-1,71)$ \\
\hline Polska & 7,63 & 0,79 & 3,93 & 4,14 & $-0,55$ & $-1,38$ \\
& $(6,50)$ & $(0,53)$ & $(1,90)$ & $(4,00)$ & $(-0,46)$ & $(-0,92)$ \\
\hline Rosja & 7,29 & 0,82 & 3,81 & 4,00 & $-0,90$ & $-2,09$ \\
& $(5,00)$ & $(0,94)$ & $(2,35)$ & $(4,00)$ & $(-0,62)$ & $(-0,93)$ \\
\hline Ukraina & 9,75 & 1,35 & 10,18 & 7,5 & $-1,24$ & $-4,49$ \\
& $(6,00)$ & $(1,18)$ & $(3,76)$ & $(7,5)$ & $(-1,28)$ & $(-4,84)$ \\
\hline \multicolumn{7}{|c|}{ Rynek dłużnych papierów wartościowych } \\
\hline Niemcy & 7,38 & 0,24 & 1,59 & 4,88 & $-0,14$ & $-0,40$ \\
& $(3,5)$ & $(0,15)$ & $(0,26)$ & $(4,00)$ & $(-0,14)$ & $(-0,26)$ \\
\hline Polska & 11,66 & 0,55 & 3,88 & 4,33 & $-0,29$ & $-0,64$ \\
& $(9,00)$ & $(0,50)$ & $(3,25)$ & $(3,00)$ & $(-0,28)$ & $(-0,59)$ \\
\hline Rosja & 18,00 & 1,29 & 11,23 & 5,50 & $(-0,41)$ & $-1,34$ \\
& $(18,00)$ & $(1,29)$ & $(\mathbf{1 1 , 2 3 )}$ & $(5,50)$ & $(-0,41)$ & $(-1,34)$ \\
\hline \multicolumn{7}{|c|}{ Rynek derywatów } \\
\hline Polska & 6,50 & 0,70 & 2,55 & 5,8 & $-0,48$ & $-1,74$ \\
& $(6,00)$ & $(0,70)$ & $(1,58)$ & $(4,9)$ & $(-0,43)$ & $(-1,20)$ \\
\hline Rosja & 16,30 & 2,52 & $\mathbf{2 9 , 0 5}$ & 2,67 & $-0,67$ & $-0,81$ \\
& $(11,00)$ & $(1,32)$ & $(6,60)$ & $(2,00)$ & $(-0,41)$ & $(-0,82)$ \\
\hline Ukraina & 5,00 & 1,79 & 5,83 & 6,00 & $-1,34$ & $-\mathbf{4 , 3 6}$ \\
& $(5,00)$ & $(1,79)$ & $(5,83)$ & $(6,00)$ & $(-1,340$ & $(-4,36)$ \\
\hline
\end{tabular}

Wartości średnie, w nawiasach mediany, D - trwałość fazy, A - amplituda, C - zmiany skumulowane. Źródło: opracowanie własne. 
obserwować na rynku akcji w Polsce i na rynku obligacji niemieckich, co świadczy o niskiej rentowności inwestycji, ale z drugiej strony - o mniejszym ryzyku w porównaniu z innymi rynkami badanej próby.

7. Porównanie wartości średnich oraz mediany wskaźników faz cyklu świadczy o dużej różnicy między nimi dla poszczególnych rynków, co potwierdza obecność szerokiego rozkładu wartości, dlatego w tych przypadkach bardziej skuteczne jest używanie wartości mediany. Takie przypadki możemy obserwować dla trwałości faz wzrostu rynków akcji (wartość średnia - 13,6 kwartału, mediana - 17 kwartałów) i dłużnych papierów wartościowych w Niemczech (wartość średnia - 7,4 kwartału, mediana - 3,5 kwartału).

W celu określenia poziomu synchronizacji rynków o różnym poziomie rozwoju obliczone zostały współczynniki konkordancji (tab. 5).

Tabela 5. Macierz współczynników konkordancji rynków instrumentów finansowych

\begin{tabular}{|c|c|c|c|c|}
\hline \multicolumn{5}{|c|}{ Rynek akcji } \\
\hline & Niemcy & Polska & Rosja & Ukraina \\
\hline Niemcy & 1 & 0,85 & 0,71 & 0,65 \\
\hline Polska & $\mathbf{0 , 8 5}$ & 1 & 0,79 & 0,81 \\
\hline Rosja & 0,71 & 0,79 & 1 & 0,70 \\
\hline Ukraina & 0,65 & 0,81 & 0,70 & 1 \\
\hline \multicolumn{5}{|c|}{ Rynek dłużnych papierów wartościowych } \\
\hline & Niemcy & Polska & Rosja & \\
\hline Niemcy & 1 & 0,73 & 0,67 & \\
\hline Polska & 0,73 & 1 & 0,93 & \\
\hline Rosja & 0,67 & 0,93 & 1 & \\
\hline \multicolumn{5}{|c|}{ Rynek derywatów } \\
\hline & Polska & Rosja & Ukraina & \\
\hline Polska & 1 & 0,54 & 0,59 & \\
\hline Rosja & 0,54 & 1 & 0,55 & \\
\hline Ukraina & 0,59 & 0,55 & 1 & \\
\hline
\end{tabular}

Źródło: opracowanie własne.

Współczynniki konkordancji rynków wszystkich krajów próby badawczej mają wartości powyżej 0,5 , co świadczy o dostatecznym poziomie synchronizacji cykli rynków zbywalnych instrumentów finansowych. Najwyższy poziom synchronizacji cykli jest pomiędzy rynkami obligacji Rosji i Polski $(0,93)$ ze względu na ich odniesienia do rynków rozwijających się. Dość wysoki poziom synchronizacji pomiędzy rynkami akcji w Polsce i w Niemczech $(0,85)$ wynika $\mathrm{z}$ integracji w ramach jednolitego obszaru finansowego UE. Najniższy poziom synchronizacji obserwujemy na rynkach derywatów, jest on skutkiem różnego poziomu rozwoju tych rynków, 
różnych rodzajów i roli umów dotyczących aktywów bazowych (w tym towarów gospodarki realnej) itp.

Tabela 6. Indeksy konkordancji cykli rynków akcji i dłużnych papierów wartościowych

\begin{tabular}{|l|c|c|c|}
\hline \multirow{2}{*}{ Kraj } & \multicolumn{3}{|c|}{ Indeksy konkordancji } \\
\cline { 2 - 4 } & $\begin{array}{c}\text { rynków akcji } \\
\text { i obligacji }\end{array}$ & $\begin{array}{c}\text { rynków akcji } \\
\text { i derywatów }\end{array}$ & $\begin{array}{c}\text { rynków obligacji } \\
\text { i derywatów }\end{array}$ \\
\hline Niemcy & $\mathbf{0 , 5 4}$ & - & - \\
\hline Polska & 0,75 & 0,61 & 0,59 \\
\hline Rosja & 0,75 & 0,71 & $\mathbf{0 , 8 3}$ \\
\hline Ukraina & - & 0,77 & - \\
\hline
\end{tabular}

Źródło: opracowanie własne.

Analiza międzysektorowa synchronizacji poszczególnych segmentów rynków zbywalnych instrumentów finansowych (tab. 6) pokazała, że wszystkie indeksy konkordancji mają wartość większą od 0,5 , co również świadczy o obecności dostatecznego poziomu synchronizacji międzysektorowej. Obecność znacznego poziomu synchronizacji cykli jest świadectwem istotnych powiązań między rynkami, które mogą się nasilać w oparciu o efekt zarażania przy realizacji niestabilności finansowej, w tym systemowej.

\section{Zakończenie}

Przeprowadzone badania empiryczne dotyczące weryfikacji zjawiska cykliczności na rynku papierów wartościowych i derywatów oraz synchronizacji wahań wybranych wskaźników rynkowych w wybranych krajach - Polsce, Ukrainie, Rosji i Niemczech - wykazały, że dla przeważającej części segmentów rynku (z wyjątkiem instrumentów pochodnych Ukrainy) istnieje tendencja do większej trwałości fazy wzrostu niż spadku. Dodatkowo wysokimi wartościami skumulowanego wzrostu rynku akcji i największymi wartościami skumulowanymi spadku we wszystkich segmentach rynku instrumentów finansowych wyróżnia się Ukraina. Wyniki te potwierdzają istotną niestabilność rynku i wrażliwość na wstrząsy. Zwłaszcza w okresie światowego kryzysu finansowego na rynku akcji Ukrainy skumulowany spadek był ponadprzeciętny w porównaniu z pozostałymi krajami regionu.

Z kolei w zakresie synchronizacji rynków badanie dowiodło istotnej zależności pomiędzy wszystkimi rynkami, szczególnie rynki obligacji Rosji i Polski były ze sobą silnie skorelowane. Badanie dowodzi, że obserwowany wzrost przepływu kapitału inwestycyjnego i integracja $\mathrm{w}$ ramach jednolitego obszaru finansowego UE może synchronizować cykle koniunkturalne, ale intensywność tego zjawiska zależy również od struktury rodzajowej rynku (akcji, obligacji, instrumentów pochodnych) i rozwoju gospodarczego kraju. 
Uzyskane wyniki badań mają istotne znaczenie z punktu widzenia przyszłego członkostwa Ukrainy w strukturach Unii Europejskiej. Rosnący stopień podobieństwa struktur gospodarczych Ukrainy i państw Unii Europejskiej powinien z korzyścią wpłynąć na stabilność tego kraju, ale i gospodarek ościennych, tj. Polski.

\section{Literatura}

Agnello L., Schuknecht L., 2009, Booms and busts in housing markets determinants and implications, ECB Working Paper, no. 1071.

Akin C., 2006, Multiple Determinants of Business Cycle Synchronization, George Washington University, Department of Economics, Washington.

Bry G., Boschan C., 1971, Cyclical analysis of economic time series: Selected procedures and computer programs, NBER Technical Working Paper, no. 20.

Claessens S., Kose A., Terrones M., 2011, Financial cycles: What? How? When?, IMF Working Paper, no. 76.

Edwards S., Biscarri J., De Gracia F., 2003, Stock market cycles, financial liberalization and volatility, Journal of International Money and Finance, vol. 22(7), s. 925-955.

Frankel J., Rose A., 1998, The endogenity of the optimum currency area criteria, The Economic Journal, no. 108.

Harding D., Pagan A., 2002, Dissecting the cycle: A methodological investigation, Journal of Monetary Economics, vol. 49(2), s. 365-381.

Jaeger A., Schuknecht L., 2004, Boom-bust phases in asset prices and fiscal policy behavior, IMF Working Paper, no. 54.

Pagan A., Sossounov K., 2003, A simple framework for analysing bull and bear markets, Journal of Applied Econometrics, vol. 18(1), s. 23-46.

Stążka-Gawrysiak A., 2011, Poland on the road to the euro: How serious is the risk of boom-bust cycles after the euro adoption? An empirical analysis, National Bank of Poland. Working Paper, no. 103. 